\title{
Jelly biomass sinking speed reveals a fast carbon export mechanism
}

\author{
Mario Lebrato, ${ }^{\mathrm{a}, *}$ Pedro de Jesus Mendes, ${ }^{\mathrm{b}}$ Deborah K. Steinberg, ${ }^{\mathrm{c}}$ Joan E. Cartes, ${ }^{\mathrm{d}}$ \\ Bethan M. Jones, ${ }^{\mathrm{e}}, 1$ Laura M. Birsa, ${ }^{\mathrm{f}}$ Roberto Benavides, ${ }^{\mathrm{a}}$ and Andreas Oschlies ${ }^{\mathrm{a}}$ \\ ${ }^{a}$ Helmholtz Centre for Ocean Research Kiel (GEOMAR), Ocean Biogeochemistry, Kiel, Germany \\ b Ocean Laboratory, Jacobs University Bremen, Bremen, Germany \\ c Virginia Institute of Marine Science, Gloucester Point, Virginia \\ dInstitut de Ciències del Mar de Barcelona, Barcelona, Spain \\ e Ocean and Earth Science, University of Southampton, National Oceanography Centre, Southampton, United Kingdom \\ f Skidaway Institute of Oceanography, Savannah, Georgia
}

\begin{abstract}
Sinking of gelatinous zooplankton biomass is an important component of the biological pump removing carbon from the upper ocean. The export efficiency, e.g., how much biomass reaches the ocean interior sequestering carbon, is poorly known because of the absence of reliable sinking speed data. We measured sinking rates of gelatinous particulate organic matter (jelly-POM) from different species of scyphozoans, ctenophores, thaliaceans, and pteropods, both in the field and in the laboratory in vertical columns filled with seawater using high-quality video. Using these data, we determined taxon-specific jelly-POM export efficiencies using equations that integrate biomass decay rate, seawater temperature, and sinking speed. Two depth scenarios in several environments were considered, with jelly-POM sinking from 200 and $600 \mathrm{~m}$ in temperate, tropical, and polar regions. Jelly-POM sank on average between 850 and $1500 \mathrm{~m} \mathrm{~d}^{-1}$ (salps: $800-1200 \mathrm{~m} \mathrm{~d}^{-1}$; ctenophores: 1200 $1500 \mathrm{~m} \mathrm{~d}^{-1}$; scyphozoans: 1000-1100 $\mathrm{m} \mathrm{d}^{-1}$; pyrosomes: $1300 \mathrm{~m} \mathrm{~d}^{-1}$ ). High latitudes represent a fast-sinking and low-remineralization corridor, regardless of species. In tropical and temperate regions, significant decomposition takes place above $1500 \mathrm{~m}$ unless jelly-POM sinks below the permanent thermocline. Sinking jelly-POM sequesters carbon to the deep ocean faster than anticipated, and should be incorporated into biogeochemical and modeling studies to provide more realistic quantification of export via the biological carbon pump worldwide.
\end{abstract}

Sinking marine particles comprise a size continuum ranging from individual cells and exudates to aggregates of degraded biogenic detritus and fecal pellets to carcasses of zooplankton, including large gelatinous zooplankton (gelatinous particulate organic matter [jelly-POM]). The sedimentation of particles to the ocean's interior is central to the biological pump concept, redistributing chemical elements in the water column and sequestering carbon to depth (Lee and Fisher 1993; Buesseler et al. 2007).

Sinking jelly-POM (also referred to as jelly falls) originates from post-bloom biomass following the seasonal collapse of gelatinous zooplankton populations (Lebrato et al. 2012), the main known contributors of which are jellyfish (Scyphozoa and Hydrozoa; Billett et al. 2006) and pelagic tunicates (Salpa and Pyrosomida; Wiebe et al. 1979; Lebrato and Jones 2009). Because gelatinous biomass is distributed from the surface to mesopelagic and deeper waters worldwide, jelly-POM is an important source of labile carbon (Condon et al. 2012). These gelatinous carcasses are occasionally exported and deposited at the seafloor, sequestering carbon and providing food for benthic communities. During jelly-POM sedimentation, large amounts of nutrients are released, providing labile resources for bacterioplankton and microzooplankton (Titelman et al. 2006; Pitt et al. 2009; Tinta et al. 2010).

\footnotetext{
*Corresponding author: mlebrato@geomar.de

${ }^{1}$ Present address: Department of Microbiology, Oregon State University, Corvallis, Oregon
}

The existence of jelly falls on the seafloor suggests a high export efficiency of at least some gelatinous taxa from the upper ocean. Alternatively, the apparent sporadic existence of jelly-POM on the seabed might suggest a poor transfer efficiency (of these or other taxa) and thus rapid remineralization of sinking jelly-POM that contributes to the dissolved carbon pool (Lebrato et al. 2011, 2012). Yet, to date, no sinking rate estimations have been made in order to investigate transfer efficiency of sinking jellyPOM.

Our understanding of particulate fluxes from field observations is limited to particles in the size range collected by sediment traps (Fowler and Knauer 1986; Asper 1987) or visible with cameras (from $<1$ to $\sim 50 \mathrm{~mm}$; Jackson et al. 1997). In the laboratory, phytoplankton- and zooplankton-derived materials (marine snow and fecal pellets) from 0.5 to $1000 \mu \mathrm{m}$ have been commonly studied (Shanks and Trent 1980; Walsby and Holland 2006; Ploug et al. 2008). However, the study of sinking rates of gelatinous zooplankton-derived POM (particles of millimeters to meters) has received little attention beyond their fecal pellets or mucous feeding webs (Silver et al. 1998; Turner 2002). The absence of fundamental data on gelatinous zooplankton carcasses prevents the implementation of a jelly-POM formulation in biogeochemical models of the biological carbon pump. Particle sinking rates increase with individual size and length (Shanks and Trent 1980) but sedimentation with depth is modeled in different ways based on theory and observations. These include particle sinking rates that increase with depth 
Table 1. Field metadata and biomass biochemistry.

\begin{tabular}{|c|c|c|c|c|c|c|}
\hline \multirow[b]{2}{*}{ Organism } & \multirow[b]{2}{*}{ Species* } & \multicolumn{5}{|c|}{ Field metadata } \\
\hline & & $n \dagger$ & Origin & Depth $(\mathrm{m}) \div$ & $T\left({ }^{\circ} \mathrm{C}\right) \S$ & Salinity§ \\
\hline Scyphozoan & Cyanea sp. & 3 & Baltic Sea & $0-10$ & 15.50 & 14.00 \\
\hline Ctenophore & Mnemiopsis leidyi & 3 & Atlantic Ocean & $0-10$ & 16.50 & 16.50 \\
\hline Thaliacean & Salpa thompsoni & 15 & Southern Ocean & $0-100$ & $1.50-0.50$ & $33.00-34.00$ \\
\hline Ctenophore & Lobate ctenophore & 13 & Southern Ocean & $0-100$ & $1.50-0.50$ & $33.00-34.00$ \\
\hline Pteropod-shelled & Limacina helicina & 8 & Southern Ocean & $0-100$ & $1.50-0.50$ & $33.00-34.00$ \\
\hline Thaliacean & Pyrosoma atlanticum & 3 & Mediterranean Sea & $0-1500$ & $24.49-13.07$ & $37.75-38.48$ \\
\hline Scyphozoan & Periphylla periphylla & 3 & Mediterranean Sea & $0-674$ & $26.34-13.06$ & $37.75-38.48$ \\
\hline Pteropod-not shelled & Cymbulia peroni & 7 & Mediterranean Sea & $0-1000$ & $25.45-13.23$ & $37.75-38.48$ \\
\hline Scyphozoan & Pelagia noctiluca & 5 & Mediterranean Sea & $0-1000$ & $25.45-13.23$ & $37.97-38.48$ \\
\hline
\end{tabular}

* Highest level of taxonomic identification is given (Antarctic ctenophores were not identified).

$\dagger$ Number of individual organisms collected in the field.

$\$$ Depth range where organisms were collected by plankton net.

$\S$ Temperature and salinity in situ at collection, or the range measured at initial and final depth by a conductivity-temperature-density device or a probe.

I Number of replicate measurements. Note that not all organisms collected were analyzed, but replicates were measured for a subset (e.g., Salpa thompsoni: eight whole organisms used, then split in half, thus $n=16$ ).

- Dry weight (dry wt) of the material measured to analyze for $\mathrm{C}$ and $\mathrm{N}$.

\# Mean $\pm 1 \mathrm{SD}$

(Schmittner et al. 2005); are constant (Fasham et al. 1990); are variable according to size (Kriest and Evans 1999); or are extremely fast, fostered by the biomineral ballast effect (Armstrong et al. 2002).

Here, we quantify the rates of jelly-POM export to the deep ocean using different bloom-forming gelatinous zooplankton species to understand jelly-POM carbon transfer efficiency and provide baseline data for future model, field, and empirical studies of the biological pump. We present the first set of qualitative laboratory and field observations of jelly-POM sinking rates in scyphozoans, salps, pyrosomes, and ctenophores. Using these data we develop a taxonomically defined jelly-POM export ratio using equations that integrate biomass decay rate, seawater temperature, and sinking speed. The ratio is separated for polar, temperate, and tropical latitudes to provide the first realistic regional estimations of jelly-POM transfer efficiency using in situ sinking speed data.

\section{Methods}

Sinking rate field experiments-Field experiments were conducted off the western Antarctic Peninsula during January and February 2011 on board the R/V Laurence M. Gould (cruise LMG1101). Salps (Salpa thompsoni, $n=$ 15), lobate ctenophores (species not identified; $n=13$ ), and also pteropods (Limacina helicina, shelled, $n=8$ for comparison with unshelled pteropods) were sampled with a plankton net $(700 \mu \mathrm{m}$ mesh) between 0 and $100 \mathrm{~m}$ (temperature $=0.50-1.50^{\circ} \mathrm{C}$, salinity $=33-34$, and density $=1026.43-1027.29 \mathrm{~kg} \mathrm{~m}^{-3}$ ) at latitudes $63-70^{\circ} \mathrm{S}$ (Table 1). Individual animals were placed in a beaker containing a small volume of seawater at ambient temperature, and this beaker was placed for a few minutes within a second, larger beaker containing hot water until animals perished. Dead salps were placed in a $20 \mathrm{~mL}$ beaker containing seawater to measure biovolume (displacement volume; in this study, only biovolume measurements were available for salps). We did not measure dead ctenophore biovolume as their bodies too easily broke apart. Pteropods were directly frozen and sent to OceanLab (Jacobs University, Bremen, Germany). In Antarctica, salps (whole bodies) and ctenophores (whole bodies or small pieces) were sunk individually in a clear Plexiglas column $57 \mathrm{~cm}$ tall, with a diameter of $12.5 \mathrm{~cm}$. The column was filled with surface seawater (to mimic in situ density) to roughly $6 \mathrm{~cm}$ below the top, and animals were released just below the water surface in a known $30 \mathrm{~cm}$ interval to assess the sinking time (only during terminal velocity). The experiments were conducted on deck in calm seas at $0^{\circ} \mathrm{C}$ while the ship was stationary. The water in the column was left to stabilize 10 minutes between sinking runs to avoid turbulence and eddies affecting subsequent trials. Once concluded, the 15 salps and 13 ctenophores were sent frozen to OceanLab to reassess the sinking speed, as described below (see Fig. 1C for a comparison and statistical significance of laboratory vs. field estimations for validation of our method).

Sinking rate laboratory experiments-Laboratory experiments were conducted at OceanLab in April 2011 on 2 separate days. Apart from the Antarctic taxa described above, we also obtained scyphozoans (Cyanea sp., $n=3$, Baltic Sea; Periphylla periphylla, $n=3$, Mediterranean Sea; Pelagia noctiluca, $n=5$, Mediterranean Sea), ctenophores (Mnemiopsis leidyi, $n=3$, Atlantic Ocean), pyrosomes (Pyrosoma atlanticum, $n=3$, Mediterranean Sea), and pteropods (Cymbulia peroni without shell, $n=7$, Mediterranean Sea; Table 1 contains field seawater temperature conditions). All organisms were sampled using a plankton net, then frozen at $-20^{\circ} \mathrm{C}$ and sent to OceanLab. We thawed all organisms for $24 \mathrm{~h}$ at $5^{\circ} \mathrm{C}$ (to prevent any degradation) in a temperature-controlled room in the same water used in the column before each experimental day. All organisms were sunk in a clear acrylic column $118.5 \mathrm{~cm}$ tall with a diameter of $19 \mathrm{~cm}$ (volume $=30$ liters) in a temperature-controlled enclosure at $10^{\circ} \mathrm{C}$ (Fig. 2). We acknowledge a possible wall effect associated with relatively large particles sinking through a narrow column. Yet, 
Table 1. Extended.

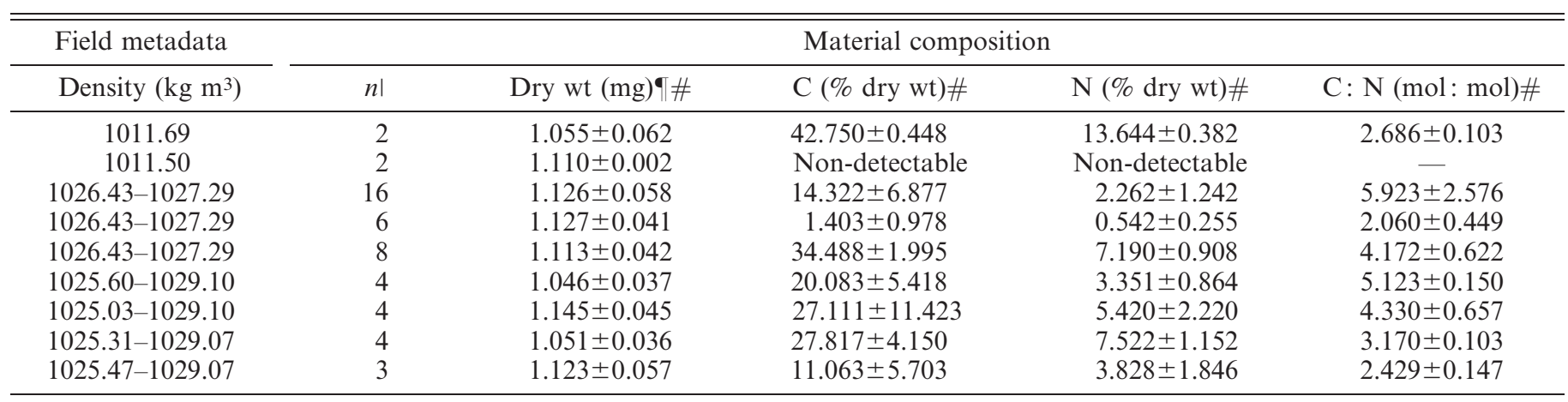

because sinking rates were high and particles did not touch walls, we posit that any wall effects were likely minimal. The column was filled with freshwater at the beginning of each experimental day. Salinity equal to field conditions was established by adding $\mathrm{NaCl}$ to the lowest value in the field samples and then progressively increased to the highest value (Tables 1, 2). Corrections to density were made for temperature changes. At any field temperature, laboratory and field density values were within $0.5 \%$ (Table 2). Using this procedure we mimicked the field density conditions independently of seawater temperature. The water in the column was left to stabilize 20 minutes between individual sinking runs to avoid turbulence and eddies affecting subsequent runs. We placed a $1 \mathrm{~m}$ ruler inside the column as a dimension reference for post-video analyses. The exact water column height was also measured before each sample was sunk (Table 2), while the whole water column was continually stirred and mixed. We recorded all sinking runs with a video camera (Canon Legria HF R16, Canon) mounted on an Erno P-55 tripod (Erno) placed $1 \mathrm{~m}$ away from the column. Videos were subsequently analyzed with ImageJ software (Abramoff et al. 2004) during which a straight line was used during terminal velocity to assess sinking rate over a distance of between 15 and $57 \mathrm{~cm}$, depending on the sample (Table 2). We conducted a total of 28 sinking runs in the field and 45 in the laboratory. To maintain the same water conditions between replicates of a particular taxon or site, all sinking runs were conducted in 1 or 2 working days (using the same water).

Elemental analyses-Immediately after the experiments concluded we froze all organisms at $-20^{\circ} \mathrm{C}$ for $12 \mathrm{~h}$ and then freeze-dried them at $60^{\circ} \mathrm{C}$ for $24 \mathrm{~h}$. Two subsamples
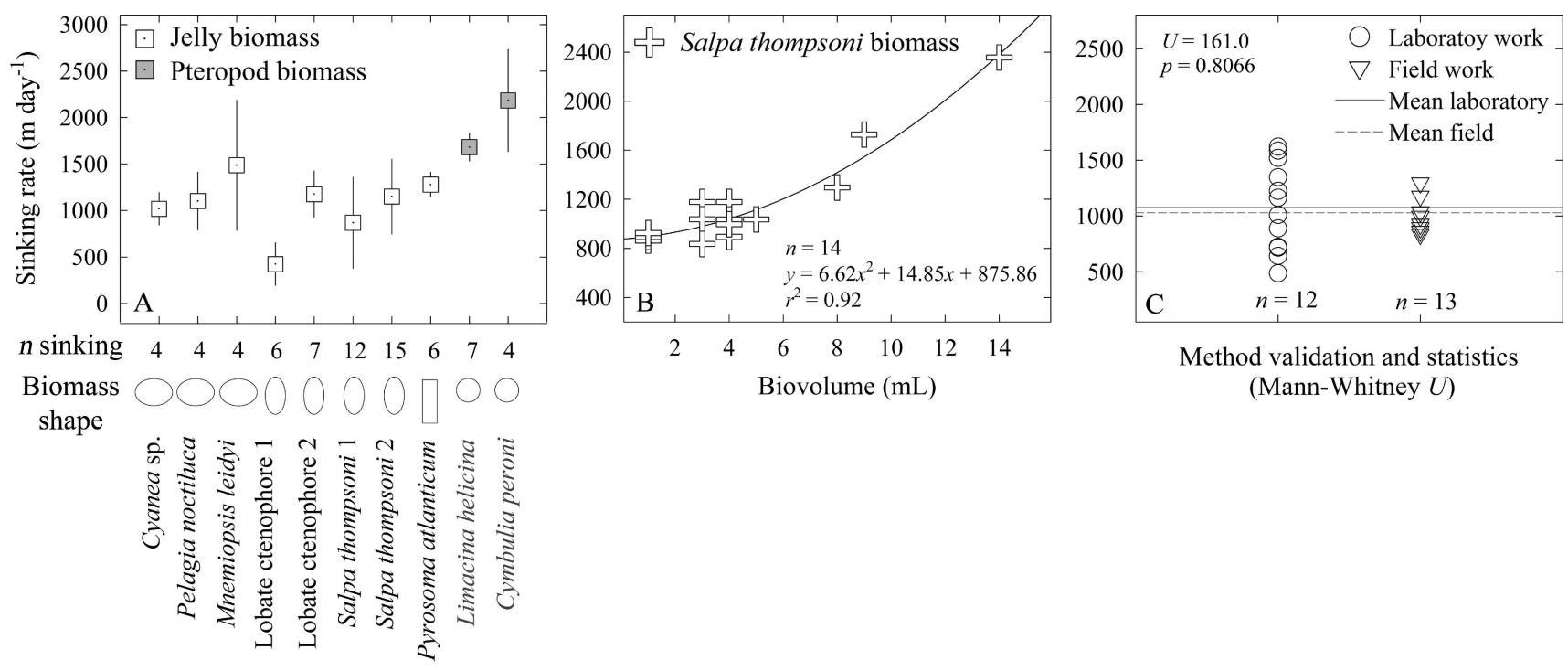

Fig. 1. (A) Sinking rates of all species studied except Periphylla periphylla (see Table 2). Error bars are 1 standard deviation. Also included is the $n$ sinking events per species. (Note that this is a survey study, thus $n$ is relatively low to allow a broader comparison. Total sinking $n=71$ during laboratory and field work). A broad biomass shape is also included for interpretation. (B) Relationship between Southern Ocean salps biomass (Salpa thompsoni), biovolume, and sinking rate, including $n$ sinking events and the predictor equation. Note that biovolume data are available only for salps in this study. (C) Comparison of freshly dead salp biomass sinking rates measured on board a ship vs. frozen-thawed sinking rates for the same animals in the laboratory. The overall mean values are very close and a Mann-Whitney $U$-test at a 95\% confidence level indicates that the difference between measurements is not significant $(p=0.8066)$. This validates our field vs. laboratory methodology for qualitative sinking rates estimations. 

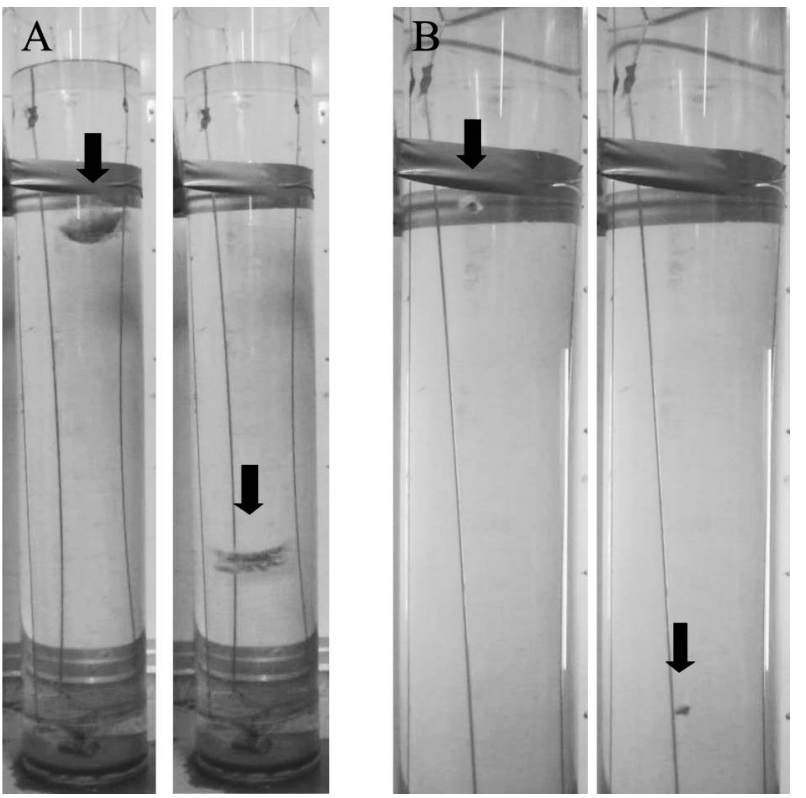

Fig. 2. The experimental sinking water column as seen from the still video camera with (A) Cyanea sp. and (B) Salpa thompsoni carcasses. Note that after each sinking event (total laboratory $n=$ 45 , total field $n=28$ ) the water column was left to stabilize for 20 minutes to avoid influence of turbulent eddies in subsequent events.

from each dried organism were weighed using a precision balance (Table 1). Samples were then carefully placed into tin vessels, which were closed for analysis. Organic carbon and nitrogen were measured using a Euro EA 3000 elemental analyzer using acetanilide standards at the Helmholtz Centre for Ocean Research Kiel (GEOMAR, Kiel, Germany).
Taxonomic separation of the jelly-POM export ratio-In order to assess the carbon-based jelly-POM export efficiency from measured sedimentation rates ( $C$ term) (Table 2; Fig. 1A), we used a newly developed export ratio calculation for gelatinous zooplankton biomass (Lebrato et al. 2011). In brief, jelly-POM remineralization can be explained by a first-order kinetic decay constant as a function of temperature $(T)$ and a gradient $\left(K_{T}\right)$, independently of the material size (Lebrato et al. 2011). This was used to develop a jelly-POM export ratio $\left(M\left(z_{\mathrm{R}}\right): M\left(z_{\mathrm{D}}\right)\right)$ relating an initial biomass $\left(M\left(z_{\mathrm{D}}\right)=M\left(z_{i-1}\right)\right)$ sinking from a given depth $z_{\mathrm{D}}\left(z_{i-1}\right)$ (called "death depth") with temperature $T\left(z_{i-1}\right)$, to a final proportion $\left(M\left(z_{\mathrm{R}}\right)=\right.$ $\left.M\left(z_{i}\right)\right)$ arriving at depth $z_{\mathrm{R}}\left(z_{i}\right)$ with temperature $T\left(z_{i}\right)$. The terms $z_{\mathrm{R}}\left(z_{i}\right)$ and $T\left(z_{i-1}\right)$ are the reference depth (or seabed) and temperature in the water column. The vertical position of $z_{\mathrm{D}}\left(z_{i-1}\right)$ is driven by the population vertical migration and the organism life history, which is species specific (Franqueville 1971). Here, we chose two death depths $\left(z_{i-1}\right)$ at $200 \mathrm{~m}$ (euphotic zone base) and $600 \mathrm{~m}$ (mesopelagic zone) following typical zooplankton biomass distribution profiles in the north Atlantic (Roe et al. 1990). The jellyPOM export ratio was calculated using a piecewise linear function dividing the depth ranges used (200-3000 $\mathrm{m}$ and $600-3000 \mathrm{~m})$ into $n$ discrete intervals $(i=200 \mathrm{~m}$ from 200 to $1000 \mathrm{~m}$, and $i=500 \mathrm{~m}$ from 1000 to $3000 \mathrm{~m}$ ) using the parameterization described in Lebrato et al. (2011) (Table 3 for input data):

$M\left(z_{i}\right): M\left(z_{i-1}\right)=e^{\left[\frac{-0.140 e^{0.145 T\left(z_{i-1}\right)}}{0.145 K_{T}(i) C}\left(e^{0.145 K_{T}(i) \Delta t C}-1\right)\right]}$

The export ratio was calculated as the product of the individual decay ratios of all linear sections $i$ :

Table 2. Sinking rate experiment summary.

\begin{tabular}{|c|c|c|c|c|c|c|c|}
\hline Organism & Species* & $\begin{array}{c}\text { Experimental water } \\
\text { height }(\mathrm{cm}) \dagger\end{array}$ & $\begin{array}{l}\text { Video distance } \\
(\mathrm{cm}) \uparrow\end{array}$ & $n \S$ & $T\left({ }^{\circ} \mathrm{C}\right) \mid$ & Salinityl & Density $\left(\mathrm{kg} \mathrm{m}^{3}\right)$ \\
\hline Scyphozoan & Cyanea sp. & 97.50 & 53.91 & 4 & 6.10 & 13.70 & 1010.78 \\
\hline Ctenophore & Mnemiopsis leidyi & 107.60 & 15.24 & 4 & 5.30 & 24.20 & 1019.12 \\
\hline Thaliacean & Salpa thompsoni 1 & 107.60 & 40.16 & 12 & 4.50 & 33.90 & 1026.88 \\
\hline Thaliacean & S. thompsoni 2 & 57.00 & 30.00 & 15 & -0.16 & 33.50 & 1026.92 \\
\hline Ctenophore & Lobate ctenophore 1 & 57.00 & 32.00 & 6 & 1.30 & 33.50 & 1026.84 \\
\hline Ctenophore & Lobate ctenophore 2 & 57.00 & 29.00 & 7 & 1.30 & 33.50 & 1026.84 \\
\hline Pteropod & Limacina helicina & 100.00 & 44.74 & 7 & 11.30 & 34.20 & 1026.12 \\
\hline Thaliacean & Pyrosoma atlanticum & 100.00 & 51.37 & 6 & 11.50 & 37.80 & 1028.89 \\
\hline Scyphozoan & Periphylla periphylla & 100.00 & 56.49 & 4 & 11.50 & 37.80 & 1028.89 \\
\hline Pteropod & Cymbulia peroni & 100.00 & 55.04 & 4 & 11.30 & 34.20 & 1026.12 \\
\hline Scyphozoan & Pelagia noctiluca & 100.00 & 50.06 & 4 & 11.50 & 37.80 & 1028.89 \\
\hline
\end{tabular}

* Highest level of taxonomic identification is given (Antarctic ctenophores could not be identified).

$\uparrow$ Water column in Plexiglas and acrylic column measured at the beginning of experiment.

$\$$ Average distance where a time measurement was taken when a carcass reached terminal velocity.

$\S$ Sinking runs. Total laboratory $=45$ events, total field $=28$ events. Replication is relatively low, but this is a qualitative study.

I Air temperature in the laboratory was maintained at $10^{\circ} \mathrm{C}$, whereas in the field (Antarctica) it was between $-0.16^{\circ} \mathrm{C}$ and $1.30^{\circ} \mathrm{C}$. Salinity in the laboratory was established by adding $\mathrm{NaCl}$ to tap water starting at the lowest density, whereas in the field (Antarctica) we used surface seawater.

- Field to laboratory density ratio (Den.field : Den.laboratory) used to check that we mimicked closely field densities to avoid major deviations from reality by using artificial seawater.

\# Mean \pm 1 SD. 


$$
M\left(z_{\mathrm{R}}\right): M\left(z_{\mathrm{D}}\right)=\prod_{i=1}^{n} M\left(z_{i}\right): M\left(z_{i-1}\right)
$$

Raw temperature data were obtained from transects in the Atlantic Ocean from 0 to $3000 \mathrm{~m}$ (World Ocean Circulation Experiment data from cruise lines A16N [04 June-11 August 2003] and A16S [11 January-24 February 2005]). We chose temperate, tropical, and polar (Antarctic) regions for which we discerned the jelly-POM export ratio based on sinking speed taxonomic differences (Table 2) and the specific temperature profiles for each region (Table 3).

Literature sinking rate data-We compiled and selected sinking speed data from the literature from a variety of particles originating in phytoplankton and zooplankton biomass, fecal material, and aggregates (see Web Appendix, Table A1, www.aslo.org/lo/toc/vol_58/issue_3/1113a. $\mathrm{html})$. Data were directly extracted from the original paper, given as individual values or as a range. Herein, we display data from previous studies using box plots to provide ranges that make them comparable to our jelly-POM measurements. We provide only a summary; thus, the dataset is not a complete representation of sinking particles in the global ocean.

Results

Sinking rate-Salps (S. thompsoni) sank on average between 800 and $1700 \mathrm{~m} \mathrm{~d}^{-1}$ depending on the sinking run, salp biovolume, and field or laboratory measurement (Table 2; Fig. 1). The material adopted an elongated shape while sinking, with a vertical orientation in the laboratory and a horizontal orientation in the field. Biovolume was assessed for this species and correlated positively with sinking rate $\left(p<0.01, r^{2}=0.92\right.$; Fig. 1B). Pieces of ctenophore ( $M$. leidyi and an unidentified lobate species) sank between 1100 and $1500 \mathrm{~m} \mathrm{~d}^{-1}$, adopting an ovoid and elongated shape, and always maintaining a vertical orientation (Table 2; Fig. 1). In comparison, ctenophore whole bodies sank much more slowly, between 400 and $600 \mathrm{~m} \mathrm{~d}^{-1}$. Scyphozoans (Cyanea sp. and Pel. noctiluca) sank between 1000 and $1100 \mathrm{~m} \mathrm{~d}^{-1}$, adopting an ovoid shape and a horizontal orientation (Table 2; Fig. 1). The scyphozoan medusa $P$. periphylla sank faster than $3500 \mathrm{~m} \mathrm{~d}^{-1}$, maintaining a spherical shape, whereas pyrosomes (Pyr. atlanticum) sank on average $1300 \mathrm{~m} \mathrm{~d}^{-1}$ with a cylindrical shape and a horizontal orientation. In comparison, pteropods ( $L$. helicina and C. peroni) sank between 1700 and $2200 \mathrm{~m} \mathrm{~d}^{-1}$, always with a spherical shape.

Elemental stoichiometry - Pteropods had on average the highest carbon content (31.13\% of dry weight), followed by scyphozoans $(26.97 \%)$, thaliaceans $(17.20 \%)$, and ctenophores $(1.40 \%)$. The highest content per species was found in Cyanea sp. (42.75\%) and the lowest in lobate ctenophores $(1.40 \%)$ (Table 1). Scyphozoans had on average the highest nitrogen content ( $7.61 \%$ of dry weight), followed by pteropods $(7.35 \%)$, thaliaceans $(2.80 \%)$, and ctenophores $(0.54 \%)$. The highest nitrogen content per species was found in Cyanea sp. (13.64\%) and the lowest in lobate ctenophores $(0.54 \%)$ (Table 1$)$. Lastly, thaliaceans had on average the highest $\mathrm{C}: \mathrm{N}$ ratio $(5.52 \mathrm{~mol}: \mathrm{mol})$, followed by pteropods (3.67), scyphozoans (3.14), and ctenophores (2.06). The highest $\mathrm{C}: \mathrm{N}$ ratio per species was found in $S$. thompsoni (5.92) and the lowest in lobate ctenophores (2.06) (Table 1).

Jelly-POM export ratio-When using $z_{\mathrm{D}}=200 \mathrm{~m}$ in tropical and temperate latitudes, high remineralization occurred down to $1500 \mathrm{~m}$, where the export ratios were

Table 2. Extended.

\begin{tabular}{|c|c|c|c|c|c|}
\hline $\begin{array}{c}\text { Den.field }_{\text {- }} \\
\text { Den.laboratory }\end{array}$ & Material sunk & Experiment & $\begin{array}{l}\text { Sinking rate } \\
\left(\mathrm{m} \mathrm{d}^{-1}\right) \#\end{array}$ & Shape & Sinking orientation \\
\hline 1.000 & All body & Laboratory & $1018 \pm 175$ & Ovoid & Horizontal \\
\hline 0.992 & Pieces & Laboratory & $1487 \pm 1126$ & Ovoid & Vertical \\
\hline 0.999 & All body & Laboratory & $868 \pm 489$ & Elongated & Vertical \\
\hline 0.999 & All body & Field & $1150 \pm 401$ & Elongated & Horizontal \\
\hline 1.000 & All body & Field & $424 \pm 228$ & Elongated & Vertical \\
\hline 1.000 & Pieces & Field & $1175 \pm 250$ & Elongated & Vertical \\
\hline 1.000 & All body & Laboratory & $1681 \pm 149$ & Sphere & - \\
\hline 0.998 & All body & Laboratory & $1278 \pm 133$ & Cylinder & Horizontal \\
\hline 0.998 & All body & Laboratory & $3892 \pm 3005$ & Sphere & - \\
\hline 1.001 & All body & Laboratory & $2183 \pm 548$ & Sphere & - \\
\hline 0.998 & All body & Laboratory & $1102 \pm 311$ & Ovoid & Vertical \\
\hline
\end{tabular}


$0.25-0.44$ and $0.14-0.31$, respectively (Fig. 3). Export ratio then decreased at $3000 \mathrm{~m}$, to $0.05-0.17$ and $0.02-0.11$, respectively. In polar latitudes (Antarctic), the export ratio remained above 0.45 for any species at $1500 \mathrm{~m}$, and above 0.13 at $3000 \mathrm{~m}$. When using $z_{\mathrm{D}}=600 \mathrm{~m}$, the tropical and temperate latitudes export ratios at $1500 \mathrm{~m}$ increased to $0.39-0.58$ and $0.38-0.57$, respectively, and at $3000 \mathrm{~m}$ export ratios increased to $0.07-0.21$ and $0.06-0.19$, respectively. In Antarctic conditions, export ratio increased to $0.55-0.70$ at $1500 \mathrm{~m}$ and to $0.15-0.34$ at $3000 \mathrm{~m}$ (Fig. 3).

\section{Discussion}

Jelly biomass sinking rate_Large particles originating from gelatinous zooplankton blooms and jelly falls have rarely been studied to date, and prior sinking rate data were scarce and often ambiguous (Moseley 1880; Apstein 1910; Mills 1981; for a review of previously published data see Web Appendix, Table A1, www.aslo.org/lo/toc/vol_58/ issue_3/1113a.html). Although exploratory and not comprehensive for all gelatinous taxa, this is the first quantitative estimation of jelly biomass sinking speed in the field and laboratory. Our dataset provides an initial overview and comparison for modelers and experimentalists to use in subsequent studies examining the role of jellyPOM in carbon export.

Our measurements of jelly biomass sinking rate vary from 400 to $1500 \mathrm{~m} \mathrm{~d}^{-1}$, which is large compared with phytoplankton-based particles (Fig. 4). For the Antarctic salp $S$. thompsoni, sinking speed increased with biovolume, indicating a size effect. The biovolume or size effect on sinking rate is known for fecal pellets (Bruland and Silver 1981). However, in large particles like gelatinous zooplankton, the specific organism material density, influenced by elemental composition, can also explain the sinking speed (Yamamoto et al. 2008). Another important factor is carcass geometry and orientation adopted while sinking. The drag coefficient changes with the material shape; therefore, carcasses resembling a sphere or an ovoid (scyphozoans and pyrosomes) tend to sink faster than those with an elongated shape. In many cases the latter have a mucous tail (observed in some ctenophores and salps), causing increased drag that reduces the overall sinking rate. The effect of shape on sinking rate is known in phytoplankton cells, where deviations from a sphere increase the drag coefficient (elongated, spicules), and thus delay sedimentation (Walsby and Xypolyta 1977; Berelson 2002; De La Rocha et al. 2008). How increasing shape complexity affects fluid dynamics has been studied in gelatinous zooplankton during vertical displacement (Katija and Dabiri 2009), with a negative correlation between shape complexity (increasing from a sphere, e.g., scyphozoan medusa, to an ellipsoid, e.g., pyrosome) and the organism volume.

Changes induced during remineralization (e.g., C:N ratio) can also affect the sinking speed as a consequence of decay rate (Lebrato et al. 2011). In general, jelly-POM has a lower $\mathrm{C}: \mathrm{N}$ ratio than that found in other zooplankton taxa (Lucas et al. 2011), with ratios 20\% lower on average (Table 1). The $\mathrm{C}: \mathrm{N}$ ratio of salp fecal material 

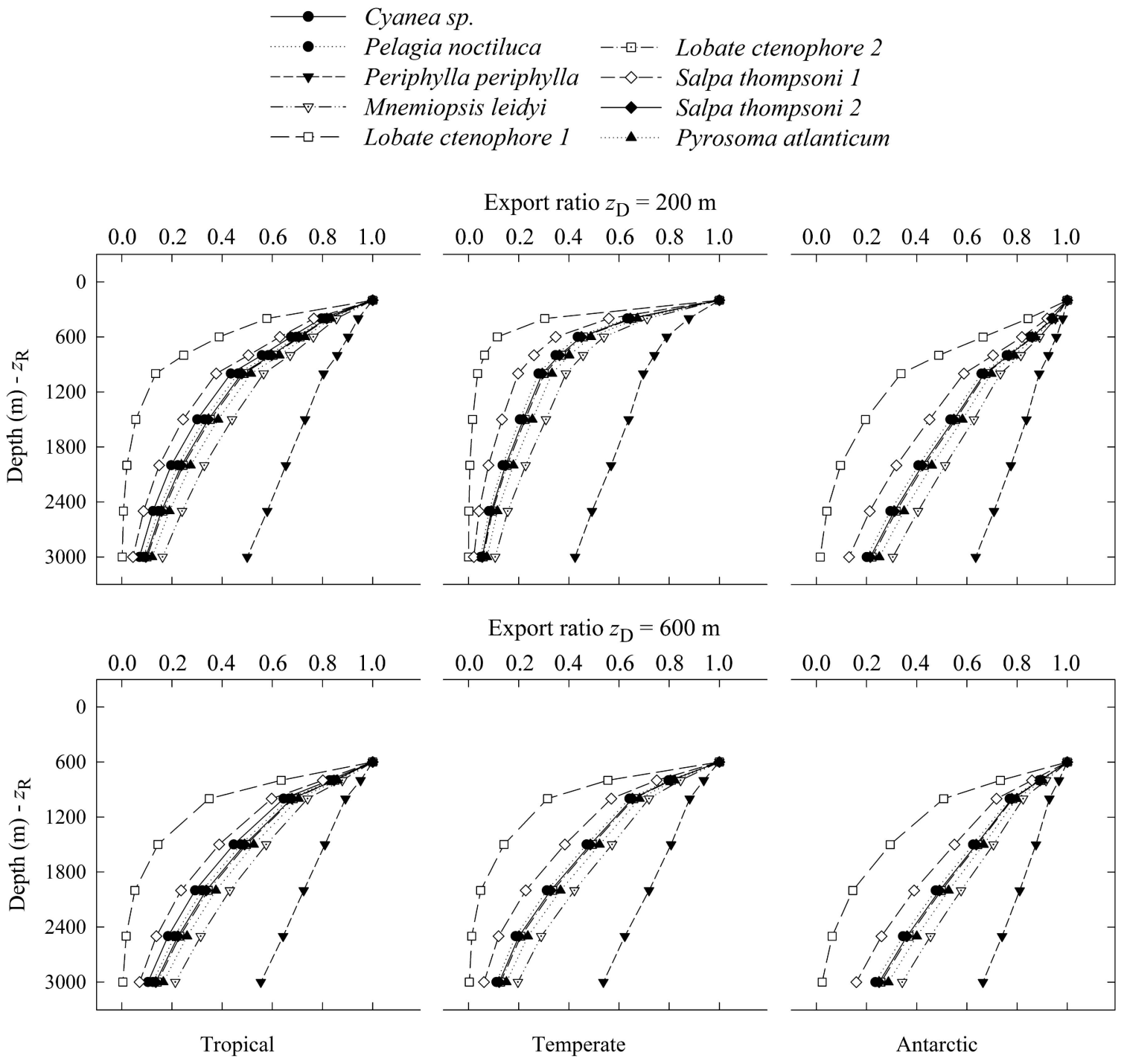

Fig. 3. Results from the simulation of the jelly-POM export ratio $M\left(z_{\mathrm{R}}\right): M\left(z_{\mathrm{D}}\right)$ for three major areas in tropical, temperate, and polar (Antarctic) latitudes. A matrix of six and eight depth intervals between the sinking depth $\left(z_{\mathrm{D}}=200\right.$ and $\left.600 \mathrm{~m}\right)$ and the reference depth $\left(z_{\mathrm{R}}=100,200,500,1000,3000\right.$, and $\left.5000 \mathrm{~m}\right)$ and five sedimentation rates $(C)\left(100,300,500,800\right.$, and $\left.1500 \mathrm{~m} \mathrm{~d}^{-1}\right)$ was used. These profiles help to separate the export ratio taxonomically.

incubated at $22^{\circ} \mathrm{C}$ for $1 \mathrm{~d}$ and then at $5^{\circ} \mathrm{C}$ for $9 \mathrm{~d}$ (resembling a transition from the euphotic to the bathypelagic zone during sinking) decreased by $11-46 \%$ of the initial values (Caron et al. 1989). During jelly-POM decay incubations, the biomass $\mathrm{C}: \mathrm{N}$ ratio quickly increases during the first 3-5 d (Titelman et al. 2006) because of preferential hydrolysis of $\mathrm{N}$ compounds with respect to $\mathrm{C}$ (Thomas et al. 1999; Anderson and Pondaven 2003) as in marine snow (Smith et al. 1992). After a few days, the C:N ratio decreases as $\mathrm{C}$ compounds are hydrolyzed, while the process is temperature dependent following biomass decay (Lebrato et al. 2011). This could cause a decrease in the sinking rate with increasing depth, although the overall high speeds observed in this study for some species would prevent major remineralization until after biomass reaches the seabed. Field evidence suggests that jelly-POM often reaches the seabed from 200 to $>3000 \mathrm{~m}$, with minor observable biomass degradation (Lebrato et al. 2012).
Sinking rates of the selected phytoplankton (except coccolithophores), marine aggregates, and most fecal pellets (see below for exception) are substantially lower than jelly-POM sinking rates (by nearly one order of magnitude; Fig. 4). Carcasses from other organisms also sink slower than jelly-POM; for example, cladocerans sink $\sim 140 \mathrm{~m} \mathrm{~d}^{-1}$, amphipods $\sim 900 \mathrm{~m} \mathrm{~d}^{-1}$, chaetognaths $\sim 400 \mathrm{~m} \mathrm{~d}^{-1}$, and copepods between 30 and $700 \mathrm{~m} \mathrm{~d}^{-1}$ (Apstein 1910; Kuenen 1950). Fecal pellets from living salps sink faster than their own carcasses in some cases, but not always (e.g., salp fecal pellet sinking rates: Salpa fusiformis $500-4000 \mathrm{~m} \mathrm{~d}^{-1}$, Pegea socia $>2000 \mathrm{~m} \mathrm{~d}^{-1}$, Salpa maxima $>1700 \mathrm{~m} \mathrm{~d}^{-1}$, S. thompsoni $200-1400 \mathrm{~m} \mathrm{~d}^{-1}$, Iasis zonaria $>900 \mathrm{~m} \mathrm{~d}^{-1}$; Bruland and Silver 1981; Madin 1982; Phillips et al. 2009). The above suggests that phytoplankton and marine snow remineralization occurs more shallowly, whereas jelly-POM can quickly sequester biomass and carbon to depth. 


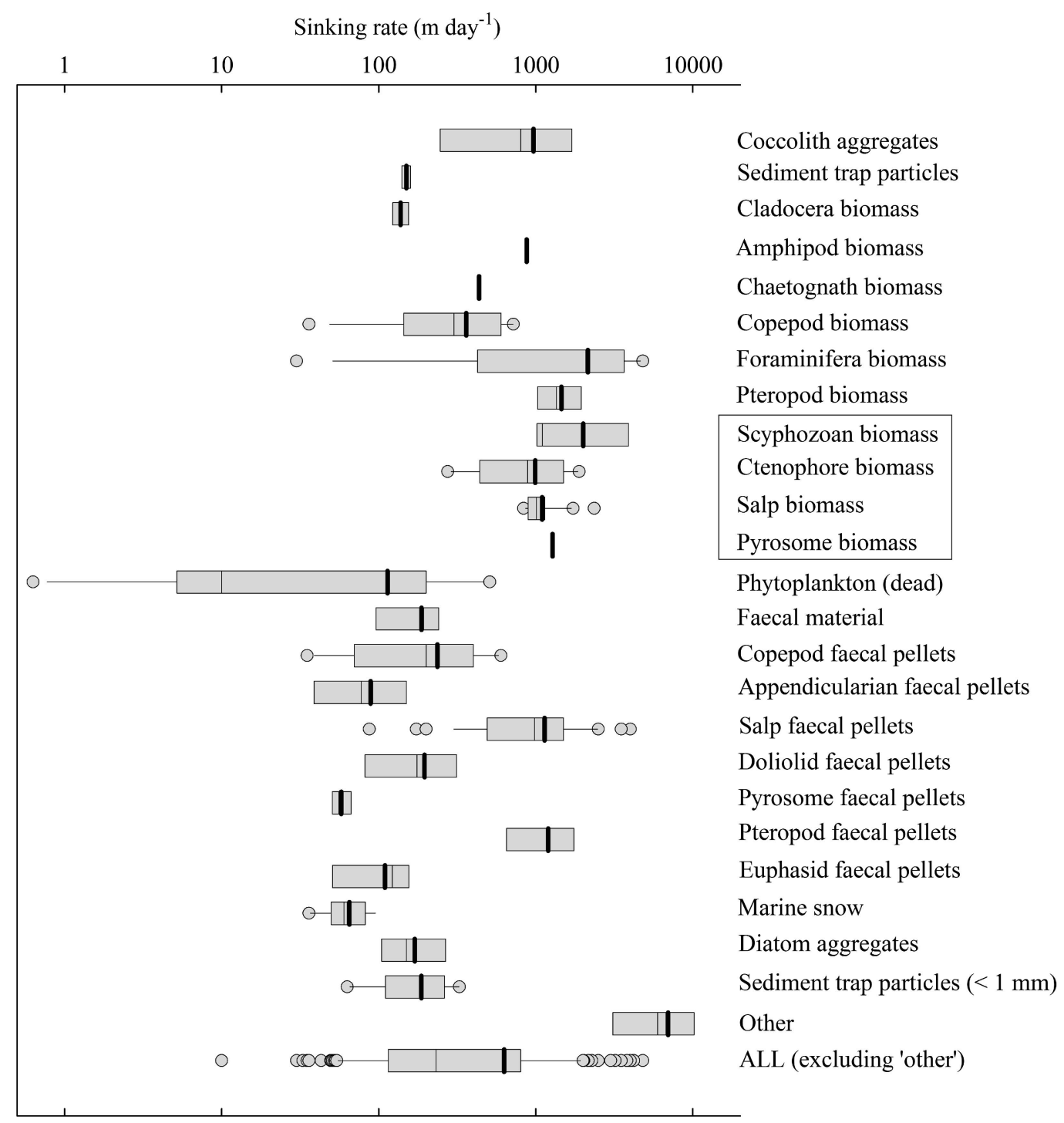

Fig. 4. Box and whisker plots of a selection of sinking rates for different marine materials and organisms (see Web Appendix, Table A1). The ends of each bar represent the 5th and 95th percentiles for all the data analyzed. The ends of each box represent the lower and upper median and the grey solid line in the box represents the main median. The bold black line indicates the grand mean. The data points outside the 5th and 95th percentile are plotted as empty circles. The taxa in a box are the new data described in this paper and compared with the rest.

Jelly-POM export efficiency-The sinking rates described here improve the jelly-POM formulation of the export ratio proposed by Lebrato et al. (2011) using a correlation of decay rate and temperature. This allows a taxonomic differentiation of carbon export potential applicable to field studies with individual taxa. Global jelly biomass datasets are becoming available and should be used to derive figures on gelatinous carbon export budgets (Condon et al. 2012). Sinking speed exerts a major control on jelly-mediated carbon export efficiency to depth because of the more rapid decay of organic material in warmer water above the thermocline vs. deeper (Lebrato et al. 2011). Simulations using a death depth $\left(z_{\mathrm{D}}\right)=0 \mathrm{~m}$ and reference depth $\left(z_{\mathrm{R}}\right)=1000 \mathrm{~m}$ in the temperate Atlantic Ocean, and an increasing sinking speed matrix, increased the jelly-POM export ratio at $1000 \mathrm{~m}$ from 0.05 using
$100 \mathrm{~m} \mathrm{~d}^{-1}$ to 0.65 using $1500 \mathrm{~m} \mathrm{~d}^{-1}$. Using the speciesspecific sinking rate described here, we compared export to $z_{\mathrm{R}}=3000 \mathrm{~m}$ by using a $z_{\mathrm{D}}=200$ and $600 \mathrm{~m}$. Overall, except in extreme cases (very low vs. high sinking speed: lobate ctenophore 2 (whole body) $=424 \mathrm{~m} \mathrm{~d}^{-1}$ vs. $P$. periphylla $\left.=3892 \mathrm{~m} \mathrm{~d}^{-1}\right)$, there was an overall high remineralization profile for all gelatinous zooplankton species at any latitude (tropical, temperate, or polar).

Our export efficiency estimations of tropical and temperate jelly-POM export ratios are similar to the organic particle results of Buesseler et al. (2007) using sediment traps. Conversely, our polar export efficiency estimates $(0.93-0.95$ at $400 \mathrm{~m}$ and $0.81-0.89$ at $600 \mathrm{~m})$ are significantly higher than those estimated in their study. They reported sediment trap carbon fluxes normalized to $150 \mathrm{~m}$ in the tropical and subarctic Pacific between $\sim 0.35$ 
and 0.70 at $300 \mathrm{~m}$ and 0.25 and 0.50 at $500 \mathrm{~m}$, respectively. This suggests that at least in polar latitudes the strength of the jelly-mediated carbon export efficiency is higher than that associated with other particle types. Thus high latitudes provide a fast-sinking corridor for jelly-POM where material is quickly exported to depth. Conversely, in tropical and temperate settings, much remineralization takes place in the upper $1500 \mathrm{~m}$ unless jelly-POM starts sinking from below the thermocline.

The vertical distribution of gelatinous zooplankton and the death depth exert a major control beyond sinking speed governing the start of remineralization and the thermal gradient encountered. This information in combination with taxon-specific sinking speed, jelly global biomass biogeography (Condon et al. 2012), and the jelly carbon export ratio (Lebrato et al. 2011), should be used to account for the contribution of gelatinous zooplankton biomass in biogeochemical models in order to generate improved assessments of the strength of the biological pump.

\section{Acknowledgments}

We thank the captain and crew of the R/V Laurence M. Gould and Raytheon Polar Services contractors for their support at sea. We also thank Kerstin Nachtigall for elemental analyses and Kate Ruck for her assistance with onboard experiments. We also thank the participants of the "Variabilidad natural y cambios inducidos por el impacto Antropogénico en la diversidad y las redes tróficas en el mar profundo en el Mediterráneo" (ANTROMARE) cruises and the crew of R/V Sarmiento de Gamboa for support. Two anonymous reviewers provided constructive comments on the manuscript. We acknowledge funding from the "European Project on Ocean Acidification" (EPOCA), part of the European Community's Seventh Framework Programme (FP7/2007-2013) (grant 211384), the Kiel Cluster of Excellence "The Future Ocean" (D1067/87), the German project Biological Impacts of Ocean Acidification (BIOACID), funded by the Federal Ministry of Education and Research (BMBF, FKZ 03F0608B), and the U.S. National Science Foundation Office of Polar Programs (grant OPP-0823101).

\section{References}

Abramoff, M., P. Magelhaes, and S. Ram. 2004. Image processing with ImageJ. Biophotonics Int. 11: 36-42.

Anderson, T. R., And P. Pondaven. 2003. Non-redfield carbon and nitrogen cycling in the Sargasso Sea: Pelagic imbalances and export flux. Deep-Sea Res. I 50: 573-591, doi:10.1016/ S0967-0637(03)00034-7

Apstein, C. 1910. Hat ein Organismus in der Tiefe Gelebt, in der er gefischt ist? Int. Rev. Hydrobiol. Hydrogr. 3: 17-33. [Has an organism into the depths lived, where it is fished?]

Armstrong, R. A., C. Lee, J. Hedges, S. Honjo, and S. WaKenam. 2002. A new, mechanistic model for organic carbon fluxes in the ocean based on the quantitative association of POC with ballast minerals. Deep-Sea Res. II 49: 219-236, doi:10.1016/S0967-0645(01)00101-1

Asper, V. L. 1987. Measuring the flux and sinking speed of marine snow aggregates. Deep-Sea Res. 4: 1-17, doi:10.1016/0198-0149 (87) $90117-8$

Berelson, W. M. 2002. Particle settling rates increase with depth in the ocean. Deep-Sea Res. II 49: 237-251, doi:10.1016/S09670645(01)00102-3
Billett, D. S. M., B. J. Bett, C. L. Jacobs, I. P. Rouse, and B. D. Wigham. 2006. Mass deposition of jellyfish in the deep Arabian Sea. Limnol. Oceanogr. 51: 2077-2083, doi:10.4319/ 10.2006.51.5.2077

Bruland, K. W., And M. W. Silver. 1981. Sinking rates of fecal pellets from gelatinous zooplankton (Salps, Pteropods, Doliolids). Mar. Biol. 63: 295-300, doi:10.1007/BF00395999

Buesseler, K. O., AND OTHERs. 2007. Revisiting carbon flux through the ocean's twilight zone. Science 316: 567-570, doi:10.1126/ science. 1137959

Caron, D. A., L. P. Madin, and J. J. Cole. 1989. Composition and degradation of salp fecal pellets: Implications for vertical flux in oceanic environments. J. Mar. Res. 47: 829-850, doi: $10.1357 / 002224089785076118$

Condon, R. H., AND others. 2012. Questioning the rise of gelatinous zooplankton in the world's oceans. BioScience 62: 161-169.

De La Rocha, C. L., N. Nowald, and U. Passow. 2008. Interactions between diatom aggregates, minerals, particulate organic carbon, and dissolved organic matter: Further implications for the ballast hypothesis. Global Biogeochem. Cycles 22: GB4005, doi:10.1029/2007GB003156

Fasham, M. J. R., H. W. Ducklow, and S. M. Mckelvie. 1990. A nitrogen based model of plankton dynamics in the oceanic mixed layer. J. Mar. Res. 48: 591-639.

Fowler, S. W., And G. A. Knauer. 1986. Role of large particles in the transport of elements and organic compounds through the oceanic water column. Prog. Oceanogr. 16: 147-194, doi:10.1016/0079-6611(86)90032-7

FrANQUEVILle, C. 1971. Macroplancton profond (invertébrés) de la Méditerranée nord-occidentale. Tethys 3: 11-56. [Deep macroplankton (invertebrates) of the northwest Mediterranean Sea.]

Jackson, G. A., R. Maffione, D. K. Costello, A. L. Alldredge, B. E. Logan, and H. G. Dam. 1997. Particle size spectra between $1 \mathrm{~mm}$ and $1 \mathrm{~cm}$ at Monterey Bay determined using multiple instruments. Deep-Sea Res. I 45: 1739-1767, doi:10. 1016/S0967-0637(97)00029-0

KatiJa, K., And J. O. Dabiri. 2009. A viscosity-enhanced mechanism for biogenic ocean mixing. Nature 460: 624-626, doi:10.1038/nature08207

Kriest, I., AND G. Evans. 1999. Representing phytoplankton aggregates in biogeochemical models. Deep-Sea Res. I 46: 1841-1859, doi:10.1016/S0967-0637(99)00032-1

Kuenen, P. H. 1950. Marine geology. Wiley.

Lebrato, M., and D. O. B. Jones. 2009. Mass deposition event of Pyrosoma atlanticum carcasses off Ivory Coast (West Africa). Limnol. Oceanogr. 54: 1197-1209, doi:10.4319/lo.2009.54. 4.1197

— M. Pahlow, A. Oschlies, K. A. Pitt, D. O. B. Jones, J.-C. Molinero, And R. H. Condon. 2011. Depth attenuation of organic matter export associated with jelly falls. Limnol. Oceanogr. 56: 1917-1928, doi:10.4319/lo.2011.56.5.1917

, AND OTHERs. 2012. Jelly-falls historic and recent observations: A synthesis to drive future research directions. Hydrobiologia 690: 227-245, doi:10.1007/s10750-012-1046-8

LeE, B.-G., AND N. Fisher. 1993. Release rate of trace elements and protein from decomposing debris 1. Phytoplankton debris. J. Mar. Res. 51: 391-421, doi:10.1357/0022240933223774

Lucas, C. H., K. A. Pitt, J. E. Purcell, M. Lebrato, and R. H. Condon. 2011. What's in a jellyfish? Proximate and elemental composition and biometric relationships for use in biogeochemical studies. Ecology 92: 1704, doi:10.1890/11-0302.1

Madin, L. P. 1982. Production, composition and sedimentation of salp fecal pellets in oceanic waters. Mar. Biol. 67: 39-45, doi:10.1007/BF00397092 
Mills, C. D. 1981. Diversity of swimming behaviours in hydromedusae as related to feeding and utilization of space. Mar. Biol. 64: 185-189, doi:10.1007/BF00397107

Moseley, H. N. 1880. Deep-sea dredging and life in the deep sea III. Nature 21: 591-593, doi:10.1038/021591a0

Phillips, B., P. Kremer, And L. P. Madin. 2009. Defecation by Salpa thompsoni and its contribution to vertical flux in the Southern Ocean. Mar. Biol. 156: 455-467, doi:10.1007/s00227-008-1099-4

Pitt, K. A., D. T. Welsh, and R. H. Condon. 2009. Influence of jellyfish blooms on carbon, nitrogen, and phosphorus cycling and plankton production. Hydrobiologia 616: 133-149, doi:10.1007/s10750-008-9584-9

Ploug, H., M. H. Iversen, And G. Fischer. 2008. Ballast, sinking velocity and apparent diffusivity within marine snow and fecal pellets: Implications and substrate turnover by attached bacteria. Limnol. Oceanogr. 53: 1878-1886, doi:10.4319/lo.2008.53.5.1878

Roe, H. S. J., D. S. M. Billett, and R. S. Lampitt. 1990. Benthic/ midwater interactions on the Madeira Abyssal Plain; evidence for biological transport pathways. Prog. Oceanogr. 24: 127-140, doi:10.1016/0079-6611(90)90025-W

Schmittner, A., A. Oschlies, X. Giraud, M. Eby, and H. L. Simmons. 2005. A global model of the marine ecosystem for longterm simulations: Sensitivity to ocean mixing, buoyancy forcing, particle sinking, and dissolved organic matter cycling. Global Biogeochem. Cycles 19: GB 3004, doi:10.1029/2004GB002283

Shanks, A. L., And J. D. Trent. 1980. Marine snow-sinking rates and potential role in vertical flux. Deep-Sea Res. 27: 137-143, doi:10.1016/0198-0149(80)90092-8

Silver, M. W., S. L. Coale, C. H. Pilskaln, and D. K. Steinberg. 1998. Giant aggregates: Importance as community centers and agents of material flux in the mesopelagic zone. Limnol. Oceanogr. 43: 498-507, doi:10.4319/lo.1998.43.3.0498

Smith, D. C., M. W. Silver, A. L. Alldredge, and F. Azam. 1992. Intensive hydrolytic activity on marine aggregates and implications for rapid particle dissolution. Nature 359: 139-141, doi:10.1038/359139a0
Thomas, S. C., C. B. Halpern, D. A. Falk, D. A. Liguori, and K A. Austin. 1999. Plant diversity in managed forests: Understory responses to thinning and fertilization. Ecol. Appl. 9: 864-879, doi:10.1890/1051-0761(1999)009[0864:PDIMFU]2.0.CO;2

Tinta, T., A. Malej, M. Kos, and V. Turk. 2010. Degradation of the Adriatic medusa Aurelia sp. by ambient bacteria. Hydrobiologia 645: 179-191, doi:10.1007/s10750-010-0223-x

Titelman, J., L. Riemann, T. A. Sornes, T. Nilsen, P GRIEKSPOOR, AND U. BAMSTEDT. 2006. Turnover of dead jellyfish, stimulation and retardation of microbial activity. Mar. Ecol. Prog. Ser. 325: 43-58, doi:10.3354/meps325043

Turner, J. T. 2002. Zooplankton fecal pellets, marine snow and sinking phytoplankton blooms. Aquat. Microbiol. Ecol. 27: 57-102, doi:10.3354/ame027057

Walsby, A. E., AND D. P. Holland. 2006. Sinking velocities of phytoplankton measured on a stable density gradient by laser scanning. J. R. Soc. 3: 429-439.

, AND A. XYPOLyta. 1977. The form resistance of chitan fibres attached to the cells of Thalassiosira fluviatilis Hustedt. Br. Phycol. J. 12: 215-223, doi:10.1080/00071617700650231

Wiebe, P. H., L. P. Madin, L. R. Haury, G. R. Harbison, and L. M. Philbin. 1979. Diel vertical migration by Salpa aspera and its potential for large-scale particulate organic matter transport to the deep-sea. Mar. Biol. 53: 249-255, doi:10.1007/BF00952433

YAмамото, J., AND OTHERS. 2008. Transportation of organic matter to the sea floor by carrion falls of the giant jellyfish Nemopilema nomurai in the Sea of Japan. Mar. Biol. 153: 311-317, doi:10.1007/s00227-007-0807-9

Associate editor: Thomas R. Anderson

Received: 30 November 2012 Amended: 04 March 2013 Accepted: 12 March 2013 